\title{
The Effect of Tax Aggressiveness, Firm Size, and Profitability on Corporate Social Responsibility Disclosure in Mining Companies
}

\author{
Dwi Retno Anggraini ${ }^{1}$, Justita Dura ${ }^{2 *}$ \\ ${ }^{1,2}$ Institut Teknologi dan Bisnis Asia Malang, Indonesia \\ ${ }^{*}$ Corresponding author: \\ Email: justitadura@asia.ac.id
}

\begin{abstract}
.
In mining companies, exploitative behavior and a lack of sense of responsibility towards the environment will threaten the sustainability of the availability of natural resources, and cause disharmony in relations with the community around the company. So it is important for mining companies to carry out social responsibility towards the environment and the community around the company so that the natural resources needed are still available. This study was conducted to determine the effect of tax aggressiveness, firm size, and profitability on corporate social responsibility disclosure in mining companies listed on the IDX. In this study CSR Disclosure is measured by disclosure criteria based on GRI indicators, tax aggressiveness is measured by income tax expense and profit before tax, Firm Size is measured using total sales, profitability is measured by the ROA (Return On Asset) indicator. This study uses quantitative methods. The population selected was 44 companies, for 2 years in 2018-2019 using the purposive sampling method, in order to obtain a sample of 15 companies that met the criteria. Data were analyzed using multiple linear regression. The results of this study indicate that tax aggressiveness has a effect on CSR Disclosure, while firm size and profitability have a negative effect on CSR Disclosure.
\end{abstract}

Keywords: Tax Aggressiveness, Firm Size, Profitability, Corporate Social Responsibility Disclosure, Mining

\section{INTRODUCTION}

In fact, the company's activities cannot be separated from social contact with the surrounding community. In the use of natural resources as raw materials for production, exploitative behavior and a lack of responsibility for the environment will threaten the sustainability of the availability of natural resources used as raw materials for production, as well as cause social disharmony with the community environment and create labor conflicts that will get worse. This is especially true for companies operating in the mining sector. Companies engaged in mining have considerable consequences for the availability of natural resources and the social environment. Mining companies exploit natural raw materials in Indonesia, The community will demand the company to pay more attention to the social consequences of its activities in achieving maximum profit when public awareness of the social impacts it will cause is higher. According to Rondinelli and London (2007), many multi-national companies cooperate with non-governmental organizations in disclosing their social responsibilities.In its development Corporate Social Responsibility can be used by 
companies as a tool to reduce criticism and protect the company's image in the eyes of the public.

Corporate Social Responsibility can also be used by the community as a tool to sue companies in carrying out their responsibilities in the social and environmental fields. In other words, social development in the community can be described through Corporate Social Responsibility. In the sense of Corporate Social Responsibility will be a picture of public health. The condition of the community is not good and the existing structure is not sustainable, this causes the management of CSR to be bad (Alvaro de Regil, 2005).In general, Corporate Social Responsibility Disclosure is influenced by several factors, including Firm Size, liquidity, profitability, leverage, share ownership, media exposure. According to Putri (2017) the factors that influence Corporate Social Responsibility include Firm Size, profitability, leverage, liquidity, and ownership base. Factors that affect Corporate Social Responsibility Disclosure in this study include tax aggressiveness, Firm Size, and profitability.Tax aggressiveness is an action taken by a company to minimize its tax burden. Therefore, not a few companies will do tax aggressiveness to reduce the tax burden that must be paid.

CSR is a company obligation that is calculated and its implementation is carried out with due observance of obedience. So that Corporate Social Responsibility Disclosure is not subject to tax. To shift the tax burden, many companies choose to carry out CSR activities. Based on research by Wardhani and Muid (2017), Rahmawati and Rohman (2019), Kusumo (2017) found that tax aggressiveness has a significant effect on Corporate Social Responsibility Disclosure.Firm Size is a size ratio that shows the size of the company with several provisions including the total amount of capital, sales income, shares, total assets and so on. Small-scale companies will disclose CSR activities more narrowly than large companies which tend to have costs to produce information. Large companies allow wider CSR disclosures, because large companies have better finances. However, according to Thendri (2009) in doing CSR, you don't have to wait to become a big entrepreneur, because the most important thing is the spirit and sense of responsibility to care, not just looking for profit. Based on research by Asyik (2017), Wardhani and Mu'id (2017), Putri (2017), Triananda, et al., (2018), Firm Size has a significant effect on CSR Disclosure.

Based on research by Andrayani (2016), Faidah et al., (2020) show that Firm Size has a negative effect on CSR Disclosure.Profitability is a company's financial ratio that shows the ability of a company to gain profit or profit. One form of ratio to measure the level of profitability of a company is ROA (Return on Assets). Companies with good performance conditions can be reflected by a high ROA value. With this, the company has the opportunity to carry out CSR activities as a form of social contract with the community. Based on research by Rahmawati \& Rohman (2019), Zulhaimi \& Nuraprianti (2019), Dewi \& Sedana (2019), profitability has a significant effect on Corporate Social Responsibility Disclosure. Based on the research results of Wardhani \& Mu'id (2017), Trinanda, et al. (2018), Hardianti (2020), profitability has no effect on 
Corporate Social Responsibility Disclosure. What distinguishes it from previous research is the object of research and the research period. The object of this research is a mining company listed on the Indonesia Stock Exchange (IDX). From the results of previous studies showing inconsistent results at different times and companies, it is necessary to review it. So this research aims to:

1. To analyze the effect of tax aggressiveness on corporate social responsibility disclosure.

2. To analyze the effect of Firm Size on corporate social responsibility disclosure.

3. To analyze the effect of profitability on corporate social responsibility disclosure.

\section{Stakeholder Theory}

Stakeholder theory was first popularized in 1984 by R. Edward Freeman. According to Freeman stakeholders as "groups or individuals who can influence or be influenced by the achievement of organizational goals". Chariri (2008) said that the company is not an entity that operates only for its own purposes but must also be able to provide benefits to its stakeholders. What is meant by stakeholders here are all internal and external parties who are able to influence or be influenced either directly or indirectly by the company. Not only prioritizing the interests of management and owners of capital, the company is also expected to prioritize the interests of employees, consumers and the surrounding environment. Because the impact of company activities is not only felt by the management, owners of capital and parties related to the company but the people around the company also feel it. Therefore, if the company does not pay attention to the interests and impacts on the community and the surrounding environment, then the company is not allowed to develop itself.

Not only seen from the level of profit earned, but also from the responsibilities and activities in the social and environmental fields around the company, the level of success of a company can be seen. One form of corporate social responsibility towards the environment and society is to run a CSR program. Therefore, if the company does not pay attention to the interests and impacts on the community and the surrounding environment, then the company is not allowed to develop itself. Not only seen from the level of profit earned, but also from the responsibilities and activities in the social and environmental fields around the company, the level of success of a company can be seen. One form of corporate social responsibility towards the environment and society is to run a CSR program. Therefore, if the company does not pay attention to the interests and impacts on the community and the surrounding environment, then the company is not allowed to develop itself. Not only seen from the level of profit earned, but also from the responsibilities and activities in the social and environmental fields around the company, the level of success of a company can be seen. One form of corporate social responsibility towards the environment and society is to run a CSR program. 


\section{Corporate Social Responsibility Disclosure}

Corporate social responsibility disclosureor often referred to as corporate information disclosure is a process of disclosing information by companies related to activities and their impacts on the environment and social conditions of the community. Corporate Social Responsibility Disclosure is very important because the disclosure of corporate social responsibility can create a mutually beneficial relationship between the company, the community and the environment. The formula for Corporate Social Responsibility Disclosure with GRI Standards is as follows:

$$
C S R D=\frac{\text { Total Items Discloced }}{94}
$$

\section{Tax Aggressiveness}

Tax aggressiveness is an action that is often carried out in large corporate groups not only in Indonesia but throughout the world. A high tax burden will be imposed on companies that earn high profits. Therefore, the company will make various efforts to reduce the taxes that must be borne, this action is called tax aggressiveness. Tax aggressiveness is an effort made by management to minimize the tax burden that must be paid by the company (Aryudanto, 2016). According to (Braithwaite, 2005) tax aggressiveness is an action taken by the company to minimize the tax burden that is not in accordance with applicable law.

CSR is a company obligation that is recognized as adisclosure is carried out in accordance with the value of propriety and fairness. So, for CSRDisclosure are not taxed and the entity is likely to use CSR activities as a tool to shift the tax burden.Companies that are aggressive towards taxes tend to carry out CSR activities more broadly, in order to protect the company's image and seek public sympathy It is expected that the higher the level of tax aggressiveness, the higher the level of CSR disclosure will be. If the company violates the social contract with the community, the company's survival can be threatened. Therefore, in carrying out its operations, the company must pay attention to the interests of the parties involved in carrying out its operational processes. The following formula is used to measure the level of tax aggressiveness:

$$
E T R=\frac{\text { Income } \operatorname{Tax} \text { Expense }}{\text { Profit Before } \operatorname{Tax}} \times 100 \%
$$

\section{Firm Size}

Firm Size is a ratio to determine the size of the company. According to Rachmawati (2008:3) Firm Size is the size of an entity that can be seen from the total asset value, total sales, market capacity, number of workers and so on. The faster the growth of the company, the bigger the size of the company, this shows that the size of the company is directly proportional to the growth of the company. The larger the size of a company, the more activities carried out, thus making a big impact on the community and shareholders. Large companies tend to disclose information more widely than small companies. Firm Size formula: 


\section{Firm Size $=$ LN $($ Total Sales $)$}

\section{Profitabilitas}

Profitability is an indicator used to measure the entity's ability to earn profits from the company's business activities. According to R. Agus Sartono (2010: 12) profitability is the company's ability to earn profits in relation to sales, total assets and own capital. The higher the profitability, the better the entity's ability to earn profit, so that the entity is able to expand its CSR activities and disclose its social responsibilities in financial statements. Companies with a high level of profitability will be motivated to disclose CSR as an effort to differentiate them from other entities. ROA shows the entity's ability to obtain net profit before tax from the total assets it owns. ROA measures how a company uses its assets to earn a profit by using all of its assets. The ROA formula is:

\section{Kerangka Hipotesis}

$$
\text { ROA }=\frac{\text { Profit Before Tax }}{\text { Tatal Asset }} \times 100 \%
$$

Mining companies must have a sense of responsibility towards the environment that can threaten the sustainability of the availability of natural resources, and cause disharmony in relations with the community around the company. So it is important for mining companies to carry out social responsibility towards the environment and the community around the company so that the natural resources needed are still available. In addition, bHigh tax burden is imposed on companies that earn high profits. Therefore, the company will make various efforts to reduce taxes that must be borne by tax aggressiveness.

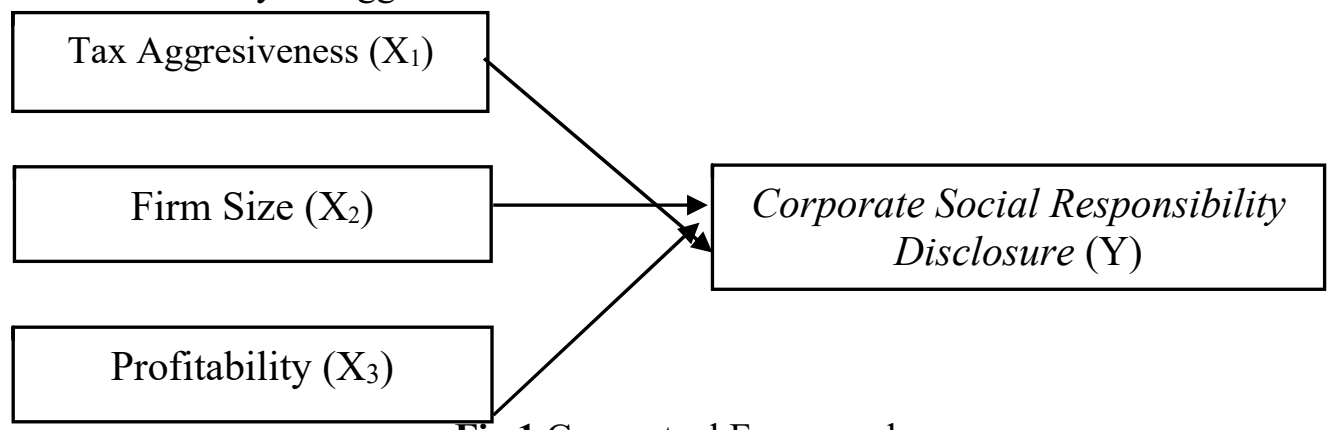

Fig 1.Conceptual Framework

The Effect of Tax Aggressiveness on Corporate Social Responsibility Disclosure

Many large companies are starting to look for ways to reduce their tax burden, namely by tax aggressiveness. Aggressiveness is an act of exploiting the weakness of existing tax rules in order to reduce the tax burden. Companies that are too aggressive towards their taxes will try to do everything they can to minimize tax payments in order to achieve their profits, one way is through wider CSR disclosures than before. Research on the effect of tax aggressiveness on CSR disclosure has been carried out by Kusumo \& Asyik (2017) that tax aggressiveness has a significant effect on CSR 
Disclosure, which means that the size of the level of tax aggressiveness will affect the level of CSR Disclosure in each company. Based on the explanation above, the following hypothesis can be formulated:

$\mathrm{H}_{1}$ : Tax aggressiveness has a positive effect on corporate social responsibility disclosure.

\section{The Influence of Firm Size on Corporate Social Responsibility Disclosure}

Firm Size is a picture of the size of a company that can be seen from its total assets. Firm Size can be measured using three methods, namely total assets, total sales, and total employees. Large companies will have broad responsibilities to their stakeholders. In this study, the method used to measure the size of the company is total sales over a certain period of time. High sales motivate entities to carry out CSR disclosures more widely than before.Research on the company's influence on CSR disclosure has been carried out by Ana Wahyuningsih, Nera Marinda Mahdar who concludes that Firm Size has a significant effect on CSR disclosure. So that it can be interpreted, companies with a high level of disclosure will be more influenced by the size of the company, compared to companies with a low level of disclosure. Based on the explanation above, the following hypothesis can be formulated:

$\mathrm{H}_{2}$ : Firm size has a positive effect on corporate social responsibility disclosure.

\section{The Effect of Profitability on Corporate Social Responsibility Disclosure}

Profitability is a financial ratio to measure a company's ability to earn a profit during a certain period. The higher the level of profitability indicates the company is in good performance condition, making it compelled to disclose more extensive information than before regarding social responsibility to stakeholders such as investors, creditors, employees, the community and the government. Based on the research of Muhammad Kafka Efendi (2019), profitability has a significant effect on CSR disclosure. It can be interpreted that if the company has good profitability, it will encourage the company to carry out CSR activities more broadly. Based on the explanation above, the following hypothesis can be formulated:

$\mathrm{H}_{3}$ : Profitability has a positive effect on corporate social responsibility disclosure

\section{METHODS}

\section{Types of Research and Data Sources}

This research is a quantitative research where the researcher emphasizes on testing theories through measuring research variables with numbers and analyzing data through statistical procedures. The type of data used in this research is secondary data.

\section{Population and Sample}

The population used in this study are all mining companies listed on the Indonesia Stock Exchange in 2018-2019. Researchers took samples using purposive sampling method, so that not too many companies were studied and obtained companies that match the predetermined criteria. The sample used is 30 companies by using certain criteria, so that the criteria for the sample in the study are as follows: 
1. Mining companies listed on the IDX in 2018-2019

2. Companies that publish annual reports in 2018-2019

There is CSR disclosure in the annual report

\section{Data Analysis Techniques and Hypothesis Test}

\section{Classic Assumption Test}

To test the feasibility of the regression model used in the study, the classical assumption test method was used(Priyanto, 2012;38). There are four ways to do in classical assumption testing, namely:

\section{a. Normality test}

The graph method and the Kolmogrov-Smirnov One-Sample test method were used to test the normality of the data. One-Sample Kolmogrov-Smirnov test to determine whether the distribution is normal, paisson, uniform, or exponential. If the residual value is more than 0.05 then the data is normally distributed(Sig 0.05$)$

\section{b. Multicollinearity Test}

Symptoms of multicollinearity in a regression model can be seen in the VIF (Variance Inflation Factor) value. The regression model is said to be good and there is no multicollinearity if the VIF value is $<10$.

\section{c. Autocorrelation Test}

Free from autocorrelation indicates a good regression model. Durbin Waston (DW) is one of the methods used to detect the presence or absence of autocorrelation in the regression model.

\section{d. Hesteroscedasticity Test}

Sperman's rho correlation is one way to determine heteroscedasticity by correlating the independent variable with the residual. The two-tailed test for this study used a significance level of 0.05 . It is said that there is heteroscedasticity if the level of significance between the independent variables and the residual is $<0.05$.

\section{Multiple Linear Regression Analysis}

Multiple Linear Regression Analysis aims to measure the intensity of two or more variables by connecting the dependent variable with two or more independent variables (Bahri, 2018; 195).

\section{Hyphothesis Test}

According to Bahri $(2018 ; 194)$ the value of $t$ can be seen in the output of the regression coefficient. To test the hypothesis of the influence between the independent variables on the dependent variable individually, the $t$ statistic test can be used. The $t$ statistic test used is as follows:

1. The significance value $>0.05$ then $\mathrm{H}_{1}$ is rejected, meaning that the $\mathrm{X}$ variable has no effect on the $\mathrm{Y}$ variable.

The significance value $<0.05$ then $\mathrm{H}_{1}$ is accepted, meaning that the $\mathrm{X}$ variable affects the $\mathrm{Y}$ variable 


\section{RESULT AND DISCUSSION}

The purpose of this study was to determine the effect of tax aggressiveness, Firm Size, and profitability on Corporate Social Responsibility Disclosure in mining companies listed on the Indonesia Stock Exchange for the period 20182019. Quantitative data is the type of data used in this study. There are 30 companies used for the sample in this study.

Classical assumption test analysis aimed at testing the feasibility of the regression model used in the study. There are four tests that must be used in the test, namely:

\section{a. Normality test}

Based on the results of the one sample Kolmogorov-Smirnov test, the value of the Kolmogorov-Smirnov/test statistic is 0.122 with a significant level of 0.200 . Based on the table, the significant value is $0.200>0.005$, it can be concluded that the data is normally distributed.

\section{b. Multicollinearity Test}

Based on the results of data processing, it shows that the VIF results from the ETR variable are 1.056, the $\mathrm{LN}$ variable is 1.048 and the ROA variable is 1.089 . The results of these calculations mean that in accordance with the above provisions that $\operatorname{VIF}<10$, it can be concluded that there is no multicollinearity in the independent variables in this regression.

\section{c. Autocorrelation Test}

Based on the results of data processing, the value of DW -2 1.6912 means that it is in an area where there is no autocorrelation. It was concluded that the research data were free from autocorrelation symptoms.

\section{d. Hesteroscedasticity Test}

Based on the results of data processing shows the correlation between variables ETR, LN, ROA with an Unstandardized Residual significance value (Sig 2 tailed) more than 0.05 . The significance level of $0.748>0.05$ means that there is no heteroscedasticity.

Multiple linear regression analysis connects the dependent variable with two or more independent variables, with the aim of measuring the intensity between these variables (Bahri, 2018; 195). The multiple linear regression equation on the results of data processing is as follows:

$$
\mathrm{CSR}=0.294+(-0.484) \mathrm{ETR}+0.004 \mathrm{LN}+(-0.275) \mathrm{ROA}+\mathrm{e}
$$

\section{Discussion}

Based on the results of research on the effect of tax aggressiveness, Firm Size, and profitability on Corporate Social Responsibility Disclosure in mining companies listed on the IDX for the period $2018-2019$, the results of hypothesis testing are obtained in Table 1. 
Table 1.Hypothesis Test Results

\begin{tabular}{|c|c|c|c|c|c|c|}
\hline \multicolumn{7}{|c|}{ Coefficients ${ }^{a}$} \\
\hline \multirow{2}{*}{\multicolumn{2}{|c|}{ Model }} & \multicolumn{2}{|c|}{ Unstandardized Coeficients } & \multirow{2}{*}{$\begin{array}{c}\begin{array}{c}\text { Standardized } \\
\text { Coefficients }\end{array} \\
\text { Beta }\end{array}$} & \multirow[b]{2}{*}{$\mathrm{t}$} & \multirow[b]{2}{*}{ Sig. } \\
\hline & & B & Std. Error & & & \\
\hline \multirow[t]{4}{*}{1} & (Constant) & .294 & .141 & & 2.086 & .047 \\
\hline & ETR & -.484 & .091 & -.744 & -5.347 & .000 \\
\hline & $L N$ & .004 & .008 & .077 & .554 & .584 \\
\hline & ROA & -.275 & .225 & -.173 & -1.222 & .233 \\
\hline
\end{tabular}

a. Dependent Variable: CSD

Analysis of Tax Aggressiveness on Corporate Social Responsibility Disclosure

Based on the results of research that have been tested, it shows that tax aggressiveness has a positive effect on CSR disclosure in mining companies listed on the IDX for the period 2018 - 2019, so that it is in accordance with the alleged hypothesis. The proof of this hypothesis is tested by a significant value whose comparison can be concluded that $\mathrm{H} 1$ is accepted, in addition to the presence of tax aggressiveness that affects CSR disclosure, it means that the greater the ETR value proves that there is an increase in CSR disclosure. Tax aggressiveness is an action to minimize the company's tax liability. This is in line with the results of previous research conducted by Wardhani \& Muid (2017) showing that tax aggressiveness has a significant effect on CSR disclosure.

\section{Firm Size Analysis on Corporate Social Responsibility Disclosure}

Based on the results of research that have been tested, it shows that Firm Size has a negative effect on CSR disclosure in mining companies listed on the IDX for the period 2018 - 2019, so it is not in accordance with the predicted hypothesis. The proof of this hypothesis is tested by a significant value whose comparison can be concluded that $\mathrm{H} 2$ is rejected. Firm Size is a scale that shows the size of an entity that can be seen from several provisions including the total amount of capital, sales income, shares, total assets and so on. This is in line with Andrayani's research (2016), which shows that Firm Size has a negative effect on CSR disclosure.

\section{Profitability Analysis On Corporate Social Responsibility Disclosure}

The results of the research that have been tested show that profitability has a negative effect on CSR disclosure in mining companies listed on the IDX for the period $2018-2019$, so there is a discrepancy with the predicted hypothesis. The proof of this hypothesis is tested by a significant value whose comparison can be concluded that $\mathrm{H} 3$ is rejected. Profitability is a financial ratio to measure the company's ability to earn a profit. ROA (Return On Assets) is one of the ratios to measure the company's ability to generate profits. This is in line with the research by Wardhani \& Mu'id (2017), profitability has a negative effect on CSR disclosure. Contrary to Rahmawati \& Rohman (2019), profitability has a positive effect on CSR disclosure. 


\section{CONCLUSION}

Based on the results if the data above can be analyzed and it can be concluded that the tax aggressiveness variable has a positive effect on CSR disclosure in mining companies listed on the Indonesia Stock Exchange (IDX) for the period 2018 - 2019. In addition, there are 2 (two) independent variables, Firm Size and profitability which have an effect negative impact on CSR disclosure in mining companies listed on the Indonesia Stock Exchange for the period 2018 - 2019.

From this it can be concluded that when a company with increased profitability and sales, the company prefers to allocate its funds for investment and funding activities rather than having to incur additional costs for CSR disclosure and when the company experiences a decline, it tends to save its funds to finance operations in the period next. The sample and variables used in this study have limitations.So for the next researchers to add research variables that affect CSR disclosure, so that they can produce more accurate research. The company is expected to pay more attention to the impact of its operational activities both in the social and environmental fields and to be responsible for the impact.

\section{ACKNOWLEDGMENTS}

I would like to thank several people who helped to complete this article, provided direction and motivation, Parents, Rector Risa Santoso, Dean, Deputy Dean, Head of Study Program \& Accounting Study Program and friends at the di Institut Teknologi dan Bisnis Asia Malang.

\section{REFERENCES}

[1] Agus, R. Sartono. 2010. Financial Management Theory and Applications. Edition. Fourth. Yogyakarta: BPFE.

[2] Andrayani, Devi (2016). The Effect of Profitability, Company Age and Firm Size on Corporate Social Responsibility (CSR) Disclosure. Institutional Repository STIE Perbanas Surabaya

[3] Aryadanto, Indra. 2016. Analysis of the Effect of Tax Aggressiveness on Disclosure of Corporate Social Responsibility in Non-Financial Companies. Diponegoro Journal of Accounting Volume 5 Number 3

[4] Bahri, Syaiful. 2018. Business Research Methodology. Yogyakarta: Andi . Publisher

[5] Braithwaite, J. (2005). Markets in Vice Markets in Virtue. Australia: National Library of Australia.

[6] Devi, et al,. 2019. The Effect of Profitability on Tax Aggressiveness with CSR Disclosure as a Moderating Variable. Udayana University Accounting E-Journal Vol. 27

[7] Dewi, et al,. 2019. The Effect of Profitability, Firm Size, and Leverage on Corporate Social Responsibility Disclosure. E-Journal of Management Vol 8 No 11 
[8] Efendi, Muhammad Kafka (2019). The Influence of Tax Aggressiveness, Firm Size, Profitability, Leverage and Public Share Ownership on Corporate Social Responsibility Disclosure. Muria Kudus University Accounting Journal

[9] Elsa, Zusandy Fitri (2019) The Effect of Tax Aggressiveness, Media Exposure and Institutional Ownership on Corporate Social Responsibility (CSR) Disclosures in Mining Companies Listed on the IDX 2015-2017. Unwidha Repository

[10] Faidah, Akhmada et al (2020) The Effect of Industry Type, Firm Size, and Profitability on Corporate Social Responsibility in Companies Listed on the IDX in 2016-2018. EJRA Vol. 09 No. 06

[11] Hardianti, Dwicitra (2020). The Influence of Firm Size, Leverage and Profitability on Corporate Social Responsibility. Journal of Accounting \& Economics (5) No. 1

[12] Kusumo, Wahyu Kencono Rukmi H and Nur Fadjrih Fun. (2017). The Influence of Tax Aggressiveness, Firm Size, Leverage, and ROA on Corporate Social Responsibility. Journal of Accounting Science and Research Volume 6, Number 12

[13] Mardikanto, Tototo. 2014. Corporate Social Responsibility. Bandung: Alphabeta

[14] Daughter, Miss Kurnia. (2017). The Influence of Firm Size, Profitability, Leverage, Liquidity, and Ownership Base on Corporate Social Responsibility in Mining Companies Listed on the Indonesia Stock Exchange (IDX) for the Period of 2012-2014. JOM Fekon Vol.4 No.1

[15] Rahmawati, Agung Putri and Abdul Rohman (2019). The Effect of Tax Aggressiveness and Company Profitability on Corporate Social Responsibility Disclosure. Diponegoro Journal of Accounting Volume 8, Number 1

[16] Rachmawati, Ike Kusdyah. 2008. Human Resource Management. Yogyakarta: ANDI

[17] Regil, A. 2005. The Future of CSR will Mirror the Health of Society: Pondering the Evolution of CSR, November 05, edition 04.

[18] Rondinelli, Dennis A. 2007. The Challenges of Restoring Governance in Crisis and Post Conflict Countries, New York Nations

[19] Trinanda, Savina Maya (2018). Analysis of the Effect of Size, Profitability and Leverage on Corporate Social Responsibility Disclosure (Empirical Study on Property and Real Estate Sector Service Companies Listed on the Indonesia Stock Exchange in 2016). Vol 1 , No.1

[20] Wahyuningsih, Ana and Nera Marinda Mahdar (2018). The Effect of Size, Leverage and Profitability on CSR Disclosure in Manufacturing Companies Listed on the Indonesia Stock Exchange. Kalbisocio, Volume 5 No.1

[21] Wardhani, Amalia Rizky and Dul Muid. (2017). The Effect of Tax Aggressiveness, Firm Size, and Profitability on Corporate Social Responsibility. Diponegoro Journal of Accounting Volume 6 (3) 1-10

[22] Zulhaimi, Hanifa and Neng Riyanti Nuraprianti (2019). The Effect of Profitability, Board of Commissioners Size, and Firm Size on Corporate Social Responsibility Disclosure. Journal of Accounting and Financial Research Vol 7 No 3 